\title{
A Review: Investigation of Bioplastics
}

\author{
Ezgi Bezirhan Arikan and Havva Duygu Ozsoy \\ Department of Environmental Engineering, Mersin University, Mersin 33343, Turkey
}

\begin{abstract}
Because of increasing environmental concerns/legislative pressure for plastics waste and rapid increases in the cost of petroleum, the development of "environmental friendly" materials has attracted extensive interest. Recently, bioplastics are one of the most innovative environmental friendly materials developed. Therefore, this paper will look at aspects of the bioplastics from the perspective of sustainability, advantages/disadvantages and standards. The global bioplastics market is thought to be growing at a rate of $20 \% \sim 25 \%$ per year. They have some advantages such as lower carbon footprint, independence, energy efficiency, and eco-safety. However, they have some disadvantages such as high cost, recycling, reducing raw materials, misused of terms and lack of legislation. For the sustainability, recycling systems and production technology may be developed for bioplastics and by-product should be used for their production. Also, there is much standardization about them. It is important to have comparable international standard methods. Therefore, there is an urgent need to standardize all details. A new guide and standard for just bioplastics should be developed for production, usage and bioplastic waste management for every country in the world.
\end{abstract}

Key words: Advantages of bioplastics, bioplastics, disadvantages of bioplastics, standards, sustainability.

\section{Introduction}

Plastic materials are currently considered very important materials due to their properties and performance over other materials such as metal and wood [1]. Worldwide annual plastics production is estimated to surpass 300 million tons by 2015 [2]. Because plastics are used in a wide range of applications, economic and environmental problems have raised.

The first environmental problem which leads to plastics is "landfill problem" [3]. Increasing amounts of plastic waste emerged as a crisis in many areas of the world because of shrinking landfill capacity, rising costs and strong legislation. The second environmental problem is "accumulation of plastics in oceans". For example, in a long-term study in the North Atlantic, one seawater sample contained the equivalent of 580,000 pieces of plastic per square kilometer [4]. Also, plastic incineration generates toxic emissions such as carbon dioxide and methane.

Corresponding author: Ezgi Bezirhan Arikan, research assistant, research fields: waste management, industrial waste management, bioplastics, and biodegrability of bioplastics. E-mail: ezgibezirhan@hotmail.com.
These GHGs (greenhouse gases) contribute to worldwide climate change [5]. The fourth problem is their "non-degradability or durability". Plastic is not biodegradable and will persist in the environment for hundreds of years [6]. The economic problem is "competition for crude oil and energy security".

In recent years, these environmental/economic problems and social concerns have triggered developing environmental friendly materials such as bioplastics [7].

Bioplastics are novel materials of the 21st century and would be of great importance to the materials world [8]. Bioplastic production and consumption will grow bigger in the future in the world. Because of this, these materials need to be evaluated carefully for sustainability and waste management. Therefore, this review provides state of performance of bioplastics materials, focusing on benefits or disadvantages of bioplastics. Also, it gives an overview of bioplastics standards.

\section{What Is Bioplastic?}

Generally, "bioplastic" are made from renewable resources such as corn, sugars, potatoes, etc. [9] and 
they are produced by a range of microorganisms [10]. There are four types of degradable plastics:

(1) Photodegradable bioplastics have light sensitive group incorporated directly into the backbone of the polymer as additives. Extensive ultraviolet radiation (several weeks to months) can disintegrate their polymeric structure rendering them open to further bacterial degradation [6];

(2) The Business-NGO (non-government organization) Working Group for Safer Chemicals and Sustainable Materials defines bio-based bioplastics as "plastics in which $100 \%$ of the carbon is derived from renewable agricultural and forestry resources such as corn starch, soybean protein and cellulose" [1];

(3) Compostable bioplastics are biologically decomposed during a composting process at a similar rate to other compostable materials and without leaving visible toxic remainders. In order to designate a plastic as bio-compostable, its total biodegradability, its disintegration degree, and the possible eco-toxicity of the degraded material must be determined by means of standard tests [11];

(4) Biodegradable bioplastics are fully degraded by microorganism without leaving visible toxic remainders. The term "biodegradable" refers to materials that can disintegrate or break down naturally into biogases and biomass (mostly carbon dioxide and water) as a result of being exposed to a microbial environment and humidity, such as the ones found in soil, hence reducing plastic waste, whereas bio-based sustainable materials. The fourth types of bioplastics are rather promising because of their actual utilization by microorganism [6].

\section{Bioplastic Market}

Researchers have developed several tools to assist in decision-making about plastics selection. One of them is the "plastic spectrum" (Fig. 1) [12, 13].

In this spectrum, bio-based bioplastics are at the right of the pyramid, indicating they are most preferable, as they are made from renewable resources, and theoretically are biodegradable and compostable [1]. Since the plastics pyramid was developed, bioplastics are much further along in their commercial development.

Packaging films and containers bioplastics are particularly interesting, since most of these products have a relative short service life and end up in landfills. Biodegradable bioplastics have been found to possess wide range of properties, which find application in biomedical field like making bone plates and screws, in drug delivery carriers and tissue engineering scaffolds $[12,14]$.

Many countries around the world have already begun to integrate these materials into their technologies. In America, McDonald is making biodegradable containers for their fast food. Other companies such as Bayer, DuPont [15], Dow Cargill, Nike, Danone, etc. are also producing biodegradable packaging.

The global bioplastics market is thought to be growing about $20 \% \sim 25 \%$ per year. Approximately $10 \% \sim 15 \%$ bioplastics of the total plastics market will increase its market share to $25 \% \sim 30 \%$ by 2020 . The bioplastic market reached over 1 billion US\$ in 2007 and it will be over 10 billion by 2020. More and more companies are entering and investing in this market.

\section{Biodegradation and Standardization of Bioplastics}

Biodegradability is an misused and abused term. Biodegradability results are strongly based on test conditions such as humidity, temperature and

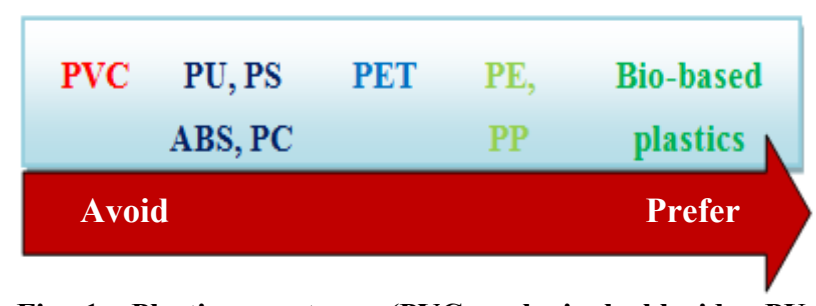

Fig. 1 Plastics spectrum (PVC: polyvinyl chloride; PU: polyurethane; PS: polystyrene; ABS: acrylonitrile butadiene styrene; PC: polycarbonate; PET: polyethylene terephthalate; PE: polyethylene; PP: polypropylene) [13]. 
microorganisms. Also, the nature is different from laboratory conditions.

The list of some available biodegradation standards is considerable (Table 1) [3]. In the interests of environmental relevance, it is recommended that selection of the test methodology be based on potential fields of application of the test polymer and its end-of-life, which is compost, soil, fresh or marine water. Some of the widely used standards are: AS4736; ASTM D5338; ASTM D6002; EN 13432; ISO 14855 (for compost exposure), ASTM D5988; ISO 17556 (for soil exposure); ASTM D6691; ASTM D6692; ISO 15314; and ISO 16221 (for marine exposure) [3].

\section{Advantages and Disadvantages of Bioplastics}

The future of biodegradable plastics shows great potential. Here are the advantages of bioplastics:

- Potentially, a much lower carbon footprint. It should be pointed out that the carbon footprint of a bioplastic is crucially dependent on whether the plastic permanently stores the carbon extracted from the air by the growing plant. A plastic made from a biological source sequesters the $\mathrm{CO}_{2}$ captured by the plant in the photosynthesis process. If the resulting bioplastic degrades back into $\mathrm{CO}_{2}$ and water, this sequestration is reversed. But a permanent bioplastic, made to be similar to polyethylene or other conventional plastics, stores the $\mathrm{CO}_{2}$ forever. Even if the plastic is recycled many times, the $\mathrm{CO}_{2}$ initially taken from the atmosphere remains sequestered [16];

- Independence. Bioplastic is made from renewable resources: corn, sugarcane, soy and other plant sources as opposed to common plastics, which are made from petroleum [17];

- Energy efficiency. Production uses less energy than conventional plastics [16]. On the other hand, plastics are made from about $4 \%$ of the oil that the world uses every year. With oil scarcity, the manufacture of plastics becomes increasingly exposed to fluctuating prices [16];

- Eco-safety. Bioplastic also generates fewer greenhouse gasses and contains no toxins. $\mathrm{Yu}$ and Chen [17] reported that bioplastics contribute clearly to the goal of mitigating GHG emissions with only $0.49 \mathrm{~kg} \mathrm{CO}$ which is being emitted from production of $1 \mathrm{~kg}$ of resin. Compared with $2 \sim 3 \mathrm{~kg} \mathrm{CO}_{2}$ of petrochemical counterparts, it is about $80 \%$ reduction of the global warming potential.

However, possible problems might come along with the use of bioplastics. Here are the disadvantages of bioplastics:

Table 1 List of some published standards for biodegradation of plastics [3].

\begin{tabular}{ll}
\hline Standard & Description \\
\hline AS 4736-2006 & Biodegradable plastics-biodegradable plastic suitable for composting and other microbial treatment \\
\hline ASTM D5209-92 & $\begin{array}{l}\text { Standard test method for determining the aerobic biodegradation of plastic materials in the presence of } \\
\text { municipal sewage sludge }\end{array}$ \\
\hline ASTM D5338-98 & $\begin{array}{l}\text { Standard test method for determining aerobic biodegradation of plastic materials under controlled } \\
\text { composting conditions }\end{array}$ \\
\hline DIN V 54900-2 & $\begin{array}{l}\text { Testing of compostability of plastics—Part 2: testing of the complete biodegradability of plastics in } \\
\text { laboratory tests }\end{array}$ \\
\hline EN 13432:2000 & $\begin{array}{l}\text { Requirements for packaging recoverable through composting and biodegradation-test scheme and } \\
\text { evaluation criteria for the final acceptance of packaging }\end{array}$ \\
\hline ISO 14851:1999 & $\begin{array}{l}\text { Determination of the ultimate aerobic biodegradability of plastic materials in an aqueous } \\
\text { medium-method by measuring the oxygen demand in a closed respirometer }\end{array}$ \\
\hline ISO 15314:2004 & $\begin{array}{l}\text { Methods for marine exposure ISO 16221:2001 water quality-guidance for the determination of } \\
\text { biodegradability in the marine environment }\end{array}$ \\
\hline CEN/TR 15822 & $\begin{array}{l}\text { Plastics: biodegradable plastics in or on soil-recovery, disposal and (under approval) related } \\
\text { environmental issues }\end{array}$ \\
\hline AFNOR NF U52-001 & $\begin{array}{l}\text { Biodegradable materials for use in agriculture and horticulture-mulching products-requirements and } \\
\text { test methods }\end{array}$ \\
\hline
\end{tabular}


- High costs. It is acclaimed that bioplastics costs two times more than conventional plastics. However, the amount of large-scale industrial production of bioplastics which are more common in the future with the implementation of cost reduction is expected;

- Recycling problems. Bioplastic material might actually contaminate the recycling process if not separated from conventional plastics. For example, working with infrared rays in waste separation system, bioplastics cannot be separated and the separating plastics might be contaminated with bioplastics;

- Reducing raw materials. Bioplastics produced from renewable sources might reduce raw material reserves. Moreover, in order to reduce energy consumption during the production of bioplastics and potential competition with agricultural resources for foods and also to provide additional raw material sources, the exploitation of food by-products is also the current trend [18];

- Misunderstanding of terms. The description of bioplastic as compostable can be confusing. All bioplastics are not compostable at home like organic food waste but usually require an industrial composting treatment which is not available at every composting site [19]. Also, bioplastics and related terms are being misused by various manufacturers to place their products more attractively on the market. Some slogans used by manufacturers such as "environmental friendly", "non-toxic", "degradable/totally degradable", are a trick with the uninformed and overwhelmed consumer;

- Lack of legislation. Production of bioplastics is projected to increase to over 6.7 million tons by the year 2018 [20]. But still, many countries have not used any law or legislation about their production, usage or waste management.

\section{Conclusions}

This review has covered the bioplastics, their types, degradability, standards, advantages and disadvantages.
There are a large number of tests which are used to determine the degradation of bioplastics. It is important to have comparable international standard methods. Unfortunately, the current standards have not been equated to each other and tend to be used in the countries where they originated. There is an urgent need to standardize all details. A new guide and standard just for bioplastics should develop for production, usage and bioplastic waste management over the world. Also, labeling legislation may be improved based on a product's raw material usage, energy consumption, emissions from manufacture and use.

Based on advantages of bioplastics, there are certainly an abundant amount of materials and resources to create and find more uses for bioplastic. Based on disadvantages of bioplastics, for the sustainability, several parameters must be considered, including the raw materials from which the bioplastic is generated, the energy consumed during bioplastic conversion and its life cycle assessment analysis from production to ultimate disposal or recycle.

\section{References}

[1] Alvarez-Chavez, C. R., Edwards, S., Moure-Eraso, R. L., and Geiser, K. 2011. "Sustainability of Bio-based Plastics: General Comparative Analysis and Recommendations for Improvement." Journal of Cleaner Production 23 (1): 46-7.

[2] Halden, R. U. 2010. "Plastics and Health Risks." Annual Review of Public Health 31: 179-94.

[3] Philp, J. C., Ritchie, R. J., and Guy, K. 2013. "Biobased Plastics in a bioecOnomy." Trends in Biotechnology 31 (2): $65-7$.

[4] Law, K. L. 2010. "Plastic Accumulation in the North Atlantic Subtropical Gyre." Science 329: 1185-8.

[5] Barker, T. 2010. Technical Summary in Climate Change 2007: Mitigation. Contribution of Working Group III to the Fourth Assessment. Report of the intergovernmental panel on climate change.

[6] El Kadi, S. 2010. Bioplastic Production form Inexpensive Sources Bacterial Biosynthesis, Cultivation System, Production and Biodegrability. USA: VDM (Verlag Dr. Müller) Publishing House.

[7] Peelman, N., Ragaert, P., de Meulenaer, B., Adons, D., 
Peeters, R., Cardon, L., et al. 2013. "Application of Bioplastics for Food Packaging." Trends in Food Science and Technology 32: 128-41.

[8] Mohanty, A. K., Misra, M., and Drzal, L. T. 2002. "Sustainable Bio-composites from Renewable Resources: Opportunities and Challenges in the Green Materials World." Journal of Polymers and the Environment 10 (1-2): 19-26.

[9] Karana, E. 2012. "Characterization of 'Natural' and 'High-Quality' Materials to Improve Perception of Bioplastics." Journal of Cleaner Production 37: 316-25.

[10] Luengo, J. M., Garcia, B., Sandoval, A., Naharro, G., and Olivera, E. R. 2003. "Bioplastics from Microorganisms." Current Opinion in Microbiology 6: 251-60.

[11] Sarasa, J., Gracia, J. M., and Javierre, C. 2008. "Study of the Biodisintegration of a Bioplastic Material Waste." Bioresource Technology 100: 3764-8.

[12] Kaith, B. S., Jindal, R., Jana, A. K., and Maiti, M. 2010. "Development of Corn Starch Based Green Composites Reinforced with Saccharum Spontaneum L Fiber and Graft Copolymers-Evaluation of Thermal, Physico-chemical and Mechanical Properties." Bioresource Technology 101: 6843-5.

[13] Iles, A., and Martin, A. N. 2013. "Expanding Bioplastics Production: Sustainable Business Innovation in the Chemical Industry." Journal of Cleaner Production 45: 38-49.
[14] Sivan, A. 2011. "New Perspectives in Plastic Biodegradation." Current Opinion in Biotechnology 22: 422-6.

[15] Krzan, A., Hemjinda, S., Miertus, S., Corti, A., and Chiellini, E. 2006. "Standardization and Certification in the Area of Environmentally Degradable Plastics." Polymer Degradation and Stability 91: 2819-33.

[16] Chen, Y. J. 2014. "Bioplastics and Their Role in Achieving Global Sustainability." Journal of Chemical and Pharmaceutical Research 6 (1): 226-31.

[17] Yu, J., and Chen, L. X. L. 2008. "The Greenhouse Gas Emissions and Fossil Energy Requirement of Bioplastics from Cradle to Gate of a Biomass Refinery." Environmental Science and Technology 42: 6961-6.

[18] Lagaron, J. M., and Lopez-Rubio, A. 2011. "Nanotechnology for Bioplastics: Opportunities, Challenges and Strategies." Trends in Food Science and Technology 22 (11): 611-7.

[19] Barker, M., and Safford, R. 2009. "Industrial Uses for Crops: Markets for Bioplastics." Accessed January 1, 2015. http://archive.hgca.com/publications/documents/ Bioplastics_web28409.pdf.

[20] European Bioplastics, Institute for Bioplastics and Biocomposites, Nova-Institute. 2014. "Production Capacity." Accessed January 1, 2015. http://en.european-bioplastics.org/market/market-develop ment/production-capacity/. 